\title{
Cytological Identification of Microfilaria in an Aberrant Location
}

\author{
S. Subapriya ", S. Vairamuthu, N. Pazhanivel, Mohammed Shafiuzama, \\ M. Gokulakrishnan and M. G. Mohammed Ali
}

Centralised Clinical Laboratory, Madras Veterinary College, Chennai-600007, TANUVAS, Tamilnadu, India

*Corresponding author

A B S T R A C T

Keywords

Dog, cytology,

Dirofilaria immitis,

microfilaria, wound

Article Info

Accepted:

15 May 2018

Available Online:

10 June 2018
This paper reports a rare and incidental finding of Microfilaria in a dog by clinical examination and cutaneous cytology. A 11 years old Rajapalayam male dog was presented to the Small Animal Clinic, Surgery unit for treatment of a swelling in the forearm region. FNAC was performed to identify the presence of neoplastic cells. However, Microfilaria organisms were identified in the cytology sediment stained by Leishman Giemsa stain. Subsequent to it blood smear was screened, which showed the presence of Microfilaria organisms with anemic changes.

\section{Introduction}

Filariasis in dogs is caused by many species of filarid nematodes. In India, Dirofilaria, Acanthocheilonema and Brugia species have been reported in dogs and cats (Gogoi, 2002; Ananda et al., 2006). Although dogs are the most important host for Dirofilaria immitis, it also infects a wide variety of mammals including human beings (Soulsby 1982; Cheng 1986).

\section{Case history and Observation}

A 11 years old, Rajapalayam breed, male dog was presented was brought to Small Animal Clinic - Out Patient - Surgery unit of Madras
Veterinary College Teaching Hospital with the history of mass in left forelimb and nonweight bearing lameness. Clinical examination revealed a soft fluctuating mass in left forearm region with pain on palpation of the mass. Fine needle aspiration cytology (FNAC) of the mass was done to evaluate the details of the mass.

\section{Results and Discussion}

FNAC smears were stained with Leishman Giemsa cocktail stain and examined under the microscope for the presence of neoplastic cells and inflammatory cells. To our surprise, cytological screening revealed the presence of microfilaria organism (Fig-1\&2) along with 
the presence of blood cells. Morphological examination revealed the presence of unsheathed microfilaria with sharp cephalic end and straight tail as described by Genchi et al., (2005). Subsequent blood smear examination revealed the presence of microfilaria organisms. Blood picture showed hypochromasia with adequate platelets.

Complete blood count revealed anaemia with Hb level $10.5 \mathrm{~g} / \mathrm{dL}$, RBC 4.88 millions/ $\mu$ l and Hematocrit $27.0 \%$. WBC count was $12,500 /$ $\mu \mathrm{l}$ and platelet count was $1,96,000 / \mu \mathrm{l}$ which were within the normal limits.

Anaemia seen in this case might be attributed by the hemolysis of RBCs and bleeding tendencies and suppression of bone marrow function (Ettinger et al., 2010).

To identify the species, morphometry was carried out. The tail tip measured $16.55 \mu \mathrm{m}$

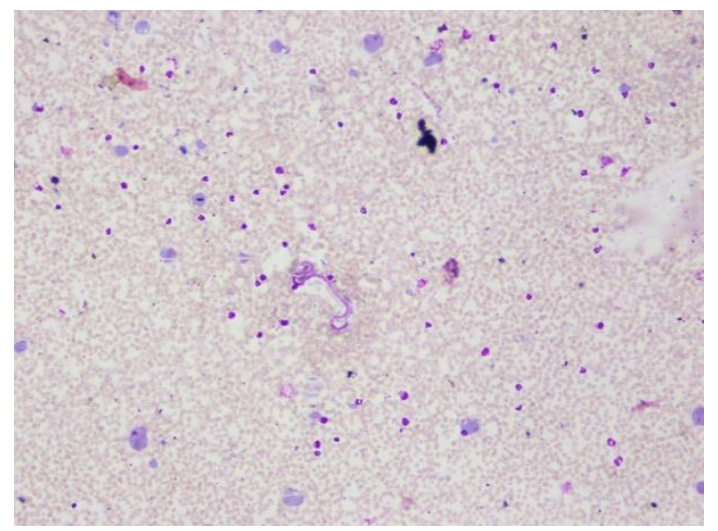

Fig-1 Microfilaria - Dog- Cytological smear Leishman Giemsa stain - 10x

Microfilaria are relatively bigger compared to other parasites and can be easily identified even under low power magnification. However the biggest challenge is, those cases which are asymptomatic, to warrant sample collection for microfilaria and its detection at ease in the smear. Hence such cases tend to be
(15-26 $\mu \mathrm{m})$, Cephalic space measured $8.3 \mu \mathrm{m}$ (3-11 $\mu \mathrm{m})$ total length was $293.82 \mu \mathrm{m}$ (292$330 \mu \mathrm{m})$ and width $5.36 \mu \mathrm{m}(5-7 \mu \mathrm{m})$. These measurements were suggestive of Dirofilaria immitis. Thus based on morphology, the microfilaria was identified as Dirofilaria immitis.

In the lifecycle of microfilaria, the adult worms reside in the pulmonary artery and right ventricle, while the larval stage microfilaria circulate in the blood stream. Many factors decide the manifestation of clinical signs like the species of microfilaria, its pathogenicity, the relative population of adultworms, duration of infection and the amount of exercise by the animal and the immune status of the host. However in few instances, microfilaria may get released into the body fluids and aberrant locations by virtue of extravasation of blood as seen in a wound in the present case.

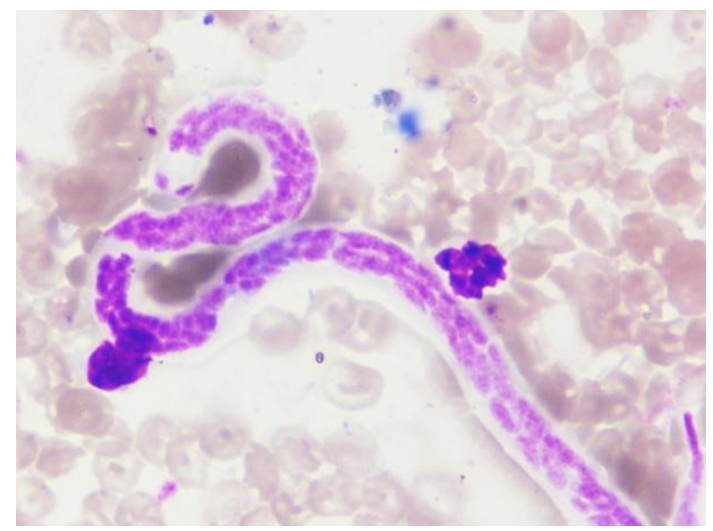

Fig-2 Microfilaria - Dog- Cytological smear Leishman Giemsa stain -100x

left undiagnosed and untreated. The asymptomatic, ailing animals may further act as a reservoir of infection and spread the disease to other animals.

Filariasis is also of public health concern with mosquitoes acting as vectors in the 
transmission of disease in animals and humans. Hence even in animals which are asymptomatic, without any overt clinical sigs of microfilariasis, when microfilaria could not be demonstrated in the blood smear, skin masses observed should be preferably screened cytologically for detection of microfilaria for early and appropriate therapeutic intervention. Thus the microfilaria of Dirofilaria immitis was recorded in a wound in the forearm region of Rajapalayam breed dog by cytological examination.

This paper is to highlight the message that microfilaria should also be in the panel of differential diagnosis of, any cutaneous masses seen in dogs apart from looking for neoplastic cells and inflammatory cells alone.

\section{Acknowledgement}

The authors are thankful to the Dean, Madras Veterinary College, for providing the necessary facilities to carry out the work.

\section{References}

Ananda, K.J., P.E. D'Souza and Jagannath, M.S. 2006. Methods for identification of microfilaria of Dirofilaria repens and Dipetalonema reconditum. Journal of Veterinary Parasitology, 20(1): 45-47

Cheng, T.C., 1986. General Parasitology. $2^{\text {nd }}$ Edn. Academic Press, Florida.

Ettinger, S.J., and Edward C.F. 2010. Textbook of Veterinary Internal Medicine. $7^{\text {th }}$ Edn. W.B. Saunders Company.

Genchi, C., L. Venco and Genchi, M. 2005. Guideline for the laboratory diagnosis of canine and feline Dirofilaria infections. Mappe Parassitologiche, 8: 139-144.

Gogoi, A.R., 2002. Filarids of animals in India. Journal of Veterinary Parasitology, 16: 131-138

Soulsby, E.J.L., 1982. Helminths, Arthropods and Protozoa of Domesticated Animals. $7^{\text {th }}$ Edn. Bailliere Tindall, London.

\section{How to cite this article:}

Subapriya S., S. Vairamuthu, N. Pazhanivel, Mohammed Shafiuzama, M. Gokulakrishnan and Mohammed Ali M. G. 2018. Cytological Identification of Microfilaria in an Aberrant Location. Int.J.Curr.Microbiol.App.Sci. 7(06): 1397-1399. doi: https://doi.org/10.20546/ijcmas.2018.706.165 